\title{
Gold(I)-Catalyzed Direct Stereoselective Synthesis of Deoxyglycosides from Glycals
}

\author{
Carlos Palo-Nieto, Abhijit Sau, and M. Carmen Galan*(0) \\ School of Chemistry, University of Bristol, Cantock's Close, Bristol BS8 1TS, United Kingdom
}

Supporting Information

ABSTRACT: $\mathrm{Au}(\mathrm{I})$ in combination with AgOTf enables the unprecedented direct and $\alpha$-stereoselective catalytic synthesis of deoxyglycosides from glycals. Mechanistic investigations suggest that the reaction proceeds via $\mathrm{Au}(\mathrm{I})$ catalyzed hydrofunctionalization of the enol ether glycoside. The room temperature reaction is high yielding and amenable to a wide range of glycal donors and $\mathrm{OH}$ nucleophiles.

S elective activation of alkyne and alkene bonds by gold catalysis has been extensively explored in organic synthesis to produce highly complex chemical architectures under mild conditions. ${ }^{1}$ Extension of these studies to oligosaccharide synthesis has resulted in the development of $\mathrm{Au}(\mathrm{III})$ and $\mathrm{Au}(\mathrm{I})$ catalyzed $\mathrm{O}$-glycosylations. ${ }^{2}$ Most reports proceed via the $\mathrm{Au}$ activation of an anomeric alkynyl in the glycosyl donor to furnish the corresponding oxonium ion which then reacts with the incoming $\mathrm{OH}$ nucleophile. ${ }^{3}$

Deoxyhexoses are often found as components of a wide range of natural products and the chiral acetal is often instrumental for their biological activity. ${ }^{4}$ Unlike fully oxygenated glycosides, the lack of substituents at C-2 to direct the nucleophile approach presents an additional synthetic challenge which has piqued the interest of many research groups. ${ }^{2 e, f, 5}$ Stemming from our interest in the development of catalytic methods for the direct stereoselective synthesis of deoxyglycosides $^{6}$ and in particular the application of transition metal catalysis for the activation of glycals. ${ }^{7}$ We proposed that the ability of Au to effect the addition of oxygen nucleophiles across $\mathrm{C}=\mathrm{C}$ bonds ${ }^{1}$ would be ideally suited for the activation of glycal enol ethers.

Herein we describe the unprecedented $\mathrm{Au}(\mathrm{I})$ direct activation of glycals to yield $\alpha$-deoxyglycosides. Products resulting from the syn addition of a proton and oxygen from the nucleophile across the carbon-carbon double bond are formed when $\left.\left[\left(p \mathrm{CF}_{3} \mathrm{Ph}\right)_{3} \mathrm{P}\right) \mathrm{AuCl}\right]$ and AgOTf are used as the glycosylation promoter (Scheme 1). Mechanistic studies suggest that the reaction proceeds via $\mathrm{Au}(\mathrm{I})$-catalyzed hydrofunctionalization of the enol ether to yield the desired glycoside with high stereocontrol.

Initial experiments began with the screening of a series of commercial $\mathrm{Au}$ catalysts: gold(III) trichloride $\left(\mathrm{AuCl}_{3}\right)$, (triphenylphosphine)gold(I) chloride $\left[\left(\mathrm{Ph}_{3} \mathrm{P}\right) \mathrm{AuCl}\right]$ and [tris( $p$-trifluoromethylphenyl)phosphine]gold(I) chloride $\left.\left[\left(p \mathrm{CF}_{3} \mathrm{Ph}\right)_{3} \mathrm{P}\right) \mathrm{AuCl}\right]$, for their ability to promote the stereoselective glycosylation of perbenzylated galactal 1a with
Scheme 1. Au-Catalysed Direct Synthesis of Deoxyglycosides from Glycals
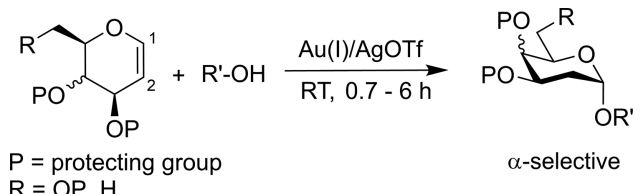

glucoside acceptor $2 \mathrm{a}^{6 \mathrm{a}}$ in $\mathrm{CH}_{2} \mathrm{Cl}_{2}$ at room temperature in the absence and presence of AgOTf as additive. As summarized in Table 1 , reactions with any of the Au catalysts in the absence of AgOTf yielded little or no product after $16 \mathrm{~h}$ (entries 1,4 and 7). Moreover, the combination of $5 \mathrm{~mol} \% \mathrm{Au}(\mathrm{III})$ and 10 mol \% AgOTf could not efficiently activate 1a and disaccharide $3 \mathrm{a}$ was obtained in a 32\% yield and a 9:1 $\alpha: \beta$ ratio within $1 \mathrm{~h}$ (entry 2). It is noteworthy that similar low yields were observed in reactions with only AgOTf after 16h (entry 3). Excitingly, activation with $\mathrm{Au}(\mathrm{I})$ proved to be more efficient and reactions in the presence of $5 \mathrm{~mol} \%\left(\mathrm{Ph}_{3} \mathrm{P}\right) \mathrm{AuCl}$ and $10 \mathrm{~mol} \% \mathrm{AgOTf}$, afforded $3 \mathrm{a}$ in $60 \%$ yield and $12: 1 \alpha: \beta$ ratio within 1 h (entry 5 ), while combinations of $\left.\left[\left(\mathrm{CF}_{3} \mathrm{Ph}\right)_{3} \mathrm{P}\right) \mathrm{AuCl}\right]$ and AgOTf gave 3a within $45 \mathrm{~min}$ and $77 \%$ yield and $>30: 1 \alpha: \beta$ stereocontrol (entry 8). Next, we decided to explore the effect of catalyst and additive loading in the model reaction. It was found that $3 \mathrm{~mol}$ $\%$ of $\left.\left[\left(p \mathrm{CF}_{3} \mathrm{Ph}\right)_{3} \mathrm{P}\right) \mathrm{AuCl}\right]$ in combination with $6 \mathrm{~mol} \%$ of AgOTf was optimal (entry 11, 89\% and $>30: 1 \alpha: \beta$ vs entry 6), with lower loadings of both components being detrimental to reaction rate (entries 9 and 10). Replacing AgOTf for either $\mathrm{AgSbF}_{6}, \mathrm{AgBF}_{4}, \mathrm{Ag}_{2} \mathrm{CO}_{3}$ or $\mathrm{BF}_{4} \mathrm{~K}$ had also a negative effect leading to either no reaction (entries 14 and 15) or intractable mixture of products (entries 12 and 13). Solvent and temperature effects were then evaluated; reactions in acetonitrile did not proceed, while reactions in toluene afforded 3a with a slight decrease in yield and stereocontrol when compared to $\mathrm{CH}_{2} \mathrm{Cl}_{2}$ (entries 16 and 17 vs 11 ). Finally, reactions carried out at $0{ }^{\circ} \mathrm{C}$ and allowed to warm to RT were slower leading to lower yields and stereocontrol (entry 18:16 h, $68 \%$ and $>20: 1 \alpha: \beta)$.

Having established the optimum reaction conditions, our attention then turned to investigating the scope of the glycal donor. To that end, a series of differentially protected galactals 1b-1f, glucals $\mathbf{4 a}$ and $\mathbf{4 b}$ and L-rhamnal $\mathbf{5}$ bearing benzyl, acetate, methoxymethyl acetal, silyl ether and siloxane protecting groups were prepared and subjected to the reaction

Received: August 20, 2017

Published: September 21, 2017 
Table 1. Initial Catalyst Screen in the Glycosylation of Galactal 1a

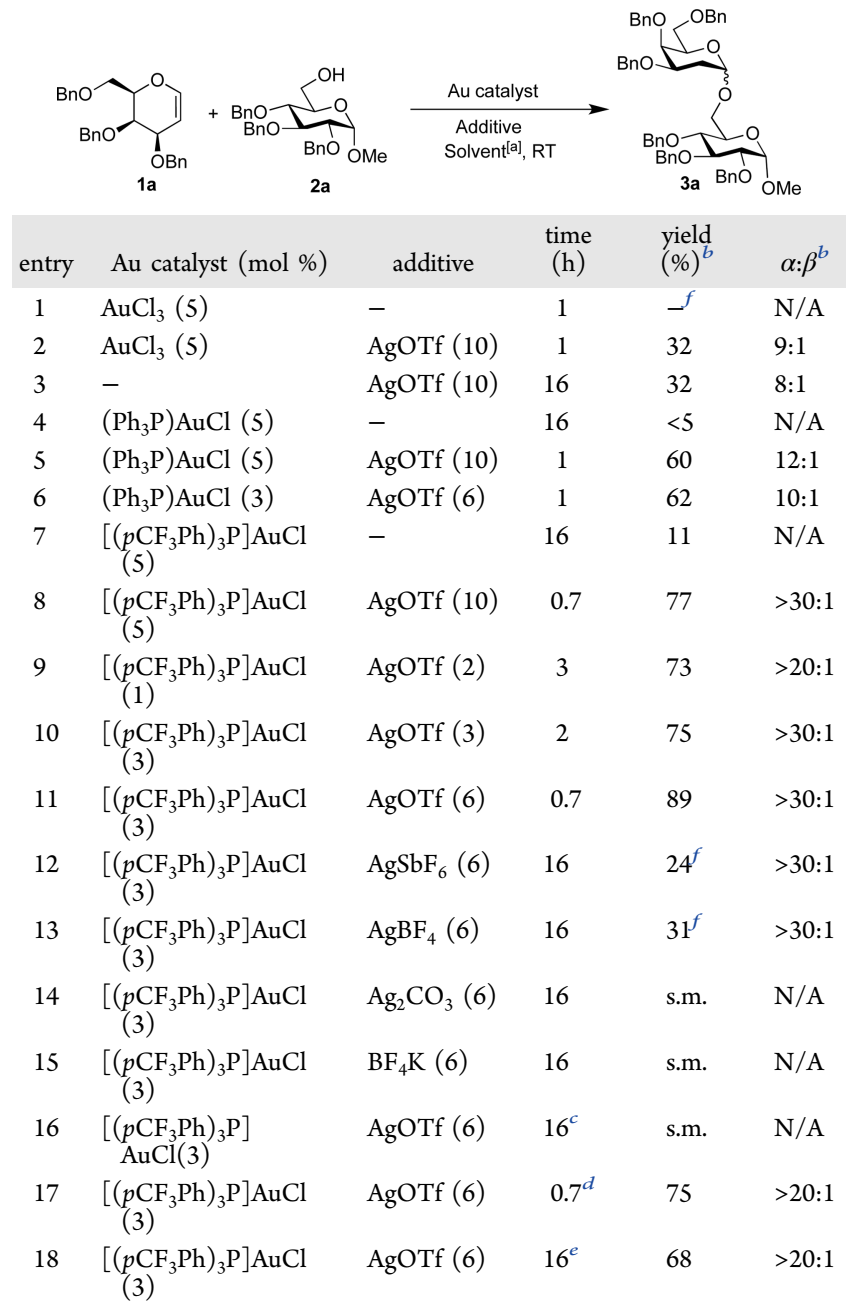

${ }^{a}$ Reactions carried out in $\mathrm{CH}_{2} \mathrm{Cl}_{2}$ unless highlighted otherwise. ${ }^{b}$ Determined by crude ${ }^{1} \mathrm{H}$ NMR. ${ }^{c}$ Reaction in $\mathrm{MeCN}$ as solvent RT. ${ }^{d}$ Reaction in Toluene as solvent. ${ }^{e}$ Reaction carried out at $-40{ }^{\circ} \mathrm{C}$ to RT. ${ }^{f}$ Inseparable mixture of products including ferrier products. s.m. = starting material. $\mathrm{N} / \mathrm{A}=$ not applicable.

conditions with $\mathbf{2 a}$ as the nucleophile (Table 2). Pleasingly, reactions involving galactal donors $\mathbf{1 b} \mathbf{b} \mathbf{1 f}$ were complete within $0.7-6 \mathrm{~h}$ and in good to excellent yields $(65-91 \%)$ and $\alpha$ selectivities (6:1 to $>30: 1 \alpha: \beta$ ratio) (entries $1-4)$, with the exception of peracetylated galactal If which gave no product (entry 5). ${ }^{8}$ Encouragingly, the reaction was also amenable to glycosylations with glucal substrates, and reactions between 3,4$O$-siloxane protected $4 a^{2 c}$ and $4 b^{2 c}$ afforded the corresponding glycosides $7 \mathbf{a}$ and $7 \mathbf{b}$ with high $\alpha$-stereocontrol $(>30: 1 \alpha: \beta)$ and yields $(78-83 \%)$ within $2-3 \mathrm{~h}$ (entries 6 and 7 ). Moreover, activation of 3,4-O-siloxane protected L-rhamnal 5 , $^{6 \mathrm{~b}}$ afforded 2,6-dideoxyglycoside 8 in $91 \%$ yield within $1 \mathrm{~h}$ and in a 5:1 $\alpha: \beta$ ratio (entry 8 ).

To explore the substrate scope of the glycosylation, galactal 1a was reacted with a range of primary and secondary $\mathrm{OH}$ nucleophiles $\mathbf{2} \mathbf{b}-\mathbf{2} \mathbf{k}$ under the optimized reaction conditions at RT (Table 3). In all cases, reactions proceeded smoothly and in good to excellent yields and $\alpha$-selectivity, demonstrating that the catalytic system tolerates the presence of common alcohol and amine protecting groups such as acetals, ethers, esters and
Table 2. Reaction of Glycals $1 b-1$, $4 a, 4 b$ and 5 with Model Glycoside Acceptor 2a

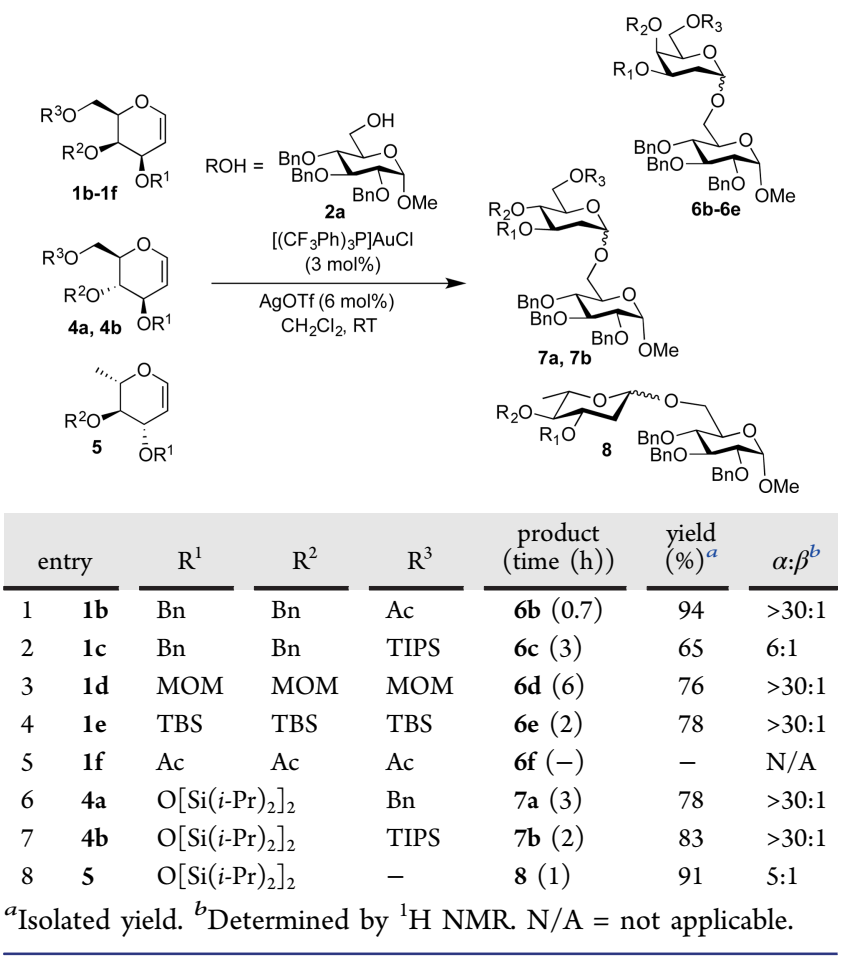

carbamates. Glycosylations with primary alcohols such as simple benzyl alcohol $\mathbf{2 b}$, glycosides $\mathbf{2 c}$ and $\mathbf{2 e}$, thioglycoside $\mathbf{2 d}$ and Boc-protected serine $\mathbf{2 f}$ afforded the corresponding glycoside products in $77-85 \%$ yield within $0.7 \mathrm{~h}$ and with an $>30: 1 \alpha: \beta$ ratio (Table 3, entries $1-5$ ). Similarly, reactions with secondary alcohols such as Boc-protected threonine $\mathbf{2 g}$, glycoside $\mathbf{2 h},(R)-(-)-1-(2$-naphtyl)ethanol $\mathbf{2} \mathbf{i}$, cholesterol $\mathbf{2 j}$ or $N$-hydroxysuccinimide $2 \mathbf{i}$ also afforded the desired products in good yields $(65-85 \%)$ and with high $\alpha$-selectivity (>30:1 $\alpha: \beta$ ratio to only $\alpha$ ) (entries $6-10$ ). These results further highlight that the catalytic system works well across a range of reactivity profiles in both the glycal moiety and nucleophile acceptor.

The synthetic utility of the $\mathrm{Au}(\mathrm{I})$-catalyzed glycosylation was demonstrated in the sequential synthesis of oligosaccharides 9$1 \mathbf{1}$ (Scheme 2). Thus, galactal $\mathbf{1 b}$ was reacted with $\mathbf{2 a}$ under the optimized $\mathrm{Au}(\mathrm{I})$ conditions, which after selective deacetylation using $\mathrm{NaOMe}$ in $\mathrm{MeOH}$ afforded acceptor 9 in $70 \%$ yield after the 2 steps, with a $>30: 1 \alpha: \beta$ selectivity. Coupling of 9 with 1a followed by ester deprotection as before, gave trisaccharide 10 in $49 \%$ yield $(>30: 1 \alpha: \beta)$. The coupling process was repeated once more and tetrasaccharide 11 was thus obtain in $52 \%$ yield and with the same high levels of $\alpha$-stereocontrol as before. While the coupling yields decreased with each glycosylation, likely due to the bulk of the glycosyl acceptor, remarkably the high diastereoselectivity is maintained.

To probe the mechanism of our reaction, a 6:1 $\alpha / \beta$-anomeric mixture of $3 a$ was subjected to the reaction conditions in the absence and presence of acceptor $\mathbf{2} \mathbf{a}$ and gave no change in the anomeric ratio, indicating that the high $\alpha$-selectivity is not the result of anomerization (Figure S2 in ESI). Reaction with deuterated galactal 12 yielded disaccharide $\mathbf{1 3}$ ( $81 \%$ yield) with the newly formed bonds cis to each other (Scheme 3 ). These results confirm that the addition of the $\mathrm{OH}$ nucleophile across the double bond is preferentially syn-diastereoselective. More- 
Table 3. Acceptor Scope in Glycosylation Reactions with Galactal 2a

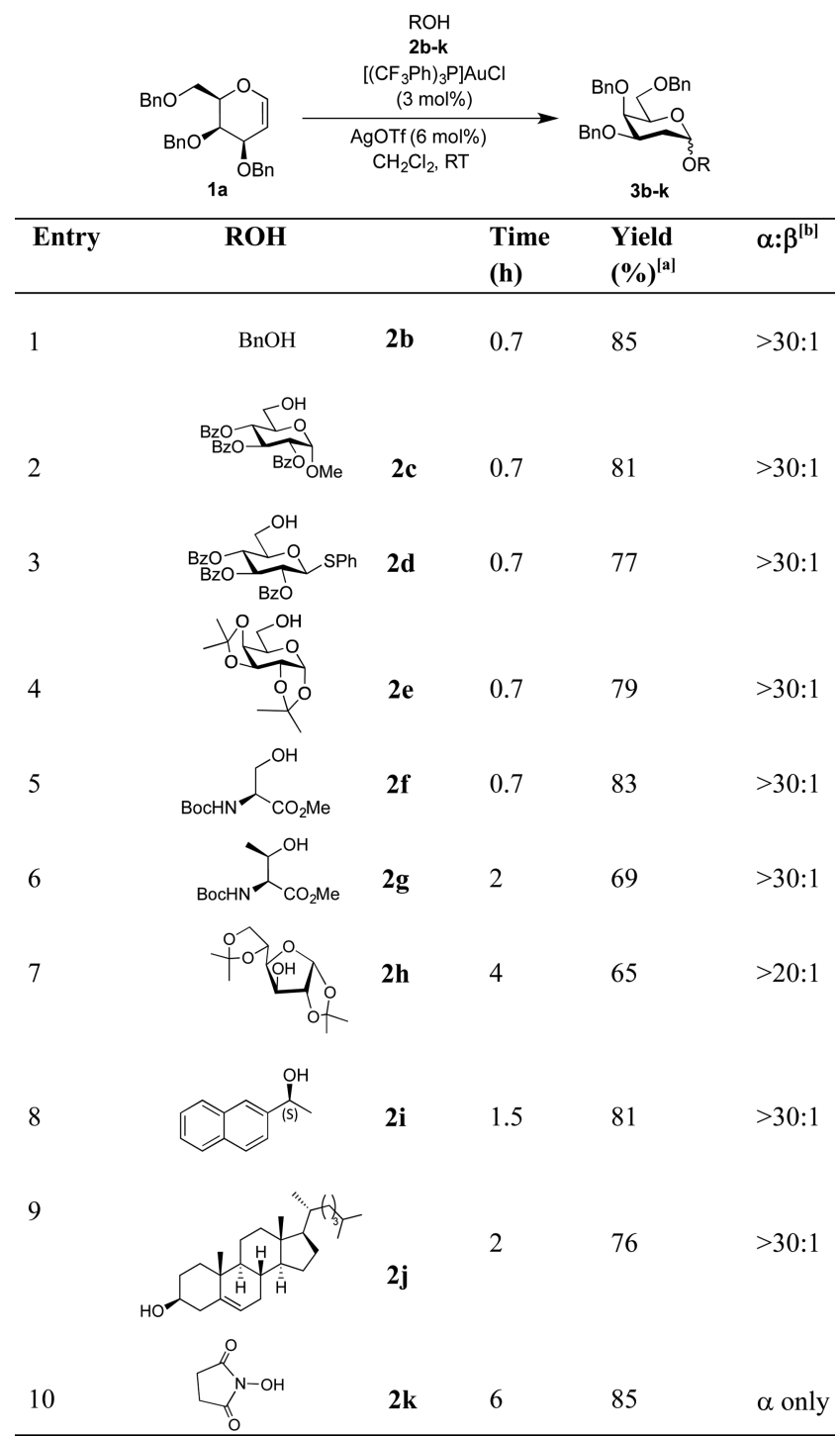

${ }^{a}$ Yield of isolated product. ${ }^{b}$ Determined by crude ${ }^{1} \mathrm{H}$ NMR.

Scheme 2. Au(I)-Catalysed Synthesis of Di-, Tri- and Tetrasaccharides 9-11

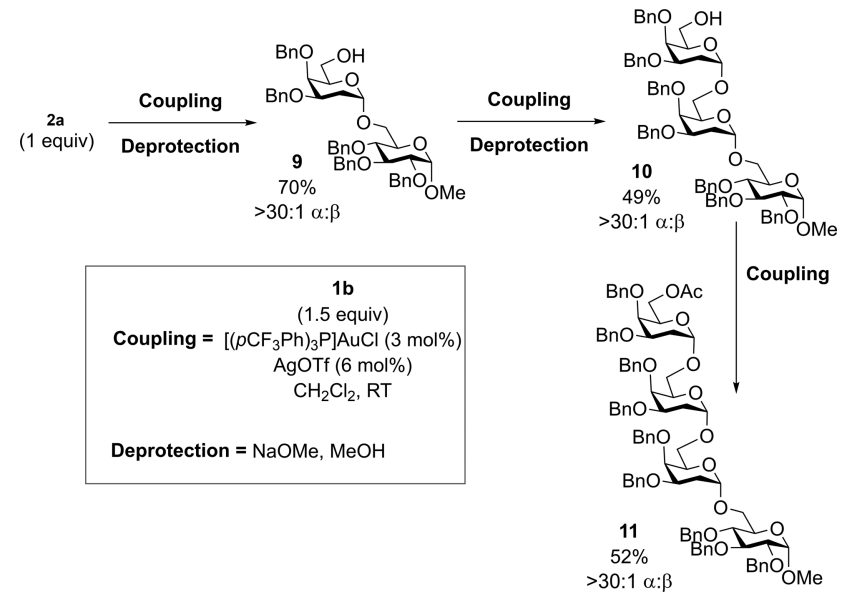

Scheme 3. Mechanistic Studies with Deuterated Glycal Donor 12 and 2a
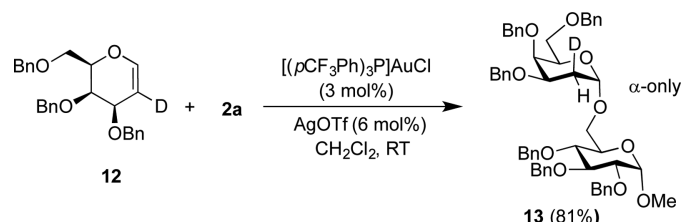

over, ${ }^{1} \mathrm{H}$ NMR spectroscopy studies in $\mathrm{CD}_{2} \mathrm{Cl}_{2}$ of mixtures of $\left.\left[\left(p \mathrm{CF}_{3} \mathrm{Ph}\right)_{3} \mathrm{P}\right) \mathrm{AuOTf}\right]$ and glycoside acceptor $2 \mathrm{a}$ did not show any changes in the spectra, suggesting there is no interaction between the Au-catalyst and the $\mathrm{OH}$ nucleophile. NMR mixtures of $\left.\left[\left(p \mathrm{CF}_{3} \mathrm{Ph}\right)_{3} \mathrm{P}\right) \mathrm{AuCl}\right], \mathrm{AgOTf}$ and glycal 1a clearly showed $\mathrm{H}$-shifts associated with the shift of alkene protons in 1a (from $\delta 6.27 \mathrm{ppm}$ to 6.67) which suggests the formation of a reactive Au carbene intermediate ${ }^{1}$ (see Figures S3 and S4 in ESI for details). This interaction is also supported by the shift observed in the IR stretch associated with the alkene signals of 1a when the Au-catalyst is present (from 1643 to $1608 \mathrm{~cm}^{-1}$ ). Additionally, monitoring of the reaction between 12 and $2 \mathrm{a}$ by ${ }^{1} \mathrm{H}$ NMR only showed signals corresponding to starting material and products (Figure S1 in ESI), suggesting the reaction proceeds via short-lived intermediates.

While a detailed mechanism awaits further examination, our initial findings suggest, as proposed in Scheme 4, that reversible

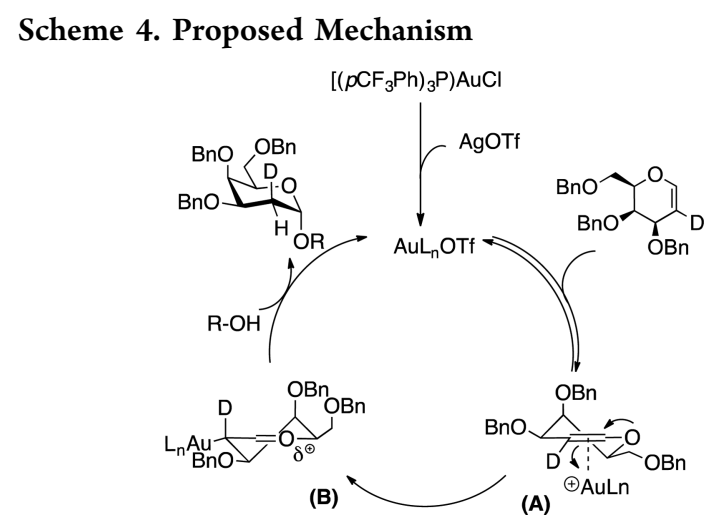

coordination of the $\mathrm{Au}(\mathrm{I})$ cation to $\mathrm{C}=\mathrm{C}$ bond leads to $\pi$ complex (A), ${ }^{9}$ which can lead to the formation of transient oxacarbenium ion (B), that is quickly trapped by the $\mathrm{OH}$ nucleophile with concomitant protonolysis of the $\mathrm{Au}-\mathrm{C}$ bond $^{9 b, 10}$ to yield the glycoside products and regenerate the $\mathrm{Au}(\mathrm{I})$ catalyst. $^{11}$

In conclusion, we have described the first example of a $\mathrm{Au}(\mathrm{I})$ catalyzed direct and stereoselective glycosylation of glycal enol ethers. This mechanistically interesting reaction is mild and widely applicable to a range of glycal donors and nucleophile acceptors. The reaction proceeds with excellent yields and high selectivity for the $\alpha$-anomer and is tolerant of most common protecting groups. We exemplify the generality and versatility of the approach in the stereoselective synthesis of a series of oligosaccharides, glycosyl-amino acids and other glycoconjugates. Given the abundance of chiral acetals in natural products, where enol ether functionalities are also featured, this method should find applications in and beyond the field of carbohydrates. 


\section{ASSOCIATED CONTENT}

\section{S Supporting Information}

The Supporting Information is available free of charge on the ACS Publications website at DOI: 10.1021 /jacs.7b08898.

Full experimental and characterization data for all compounds, including NMR spectra (PDF)

\section{AUTHOR INFORMATION}

Corresponding Author

*m.c.galan@bris.ac.uk

ORCID $\odot$

M. Carmen Galan: 0000-0001-7307-2871

Notes

The authors declare no competing financial interest.

\section{ACKNOWLEDGMENTS}

This research was supported by EPSRC CAF EP/J002542/1 and ERC-COG: 648239 (M.C.G. and A.S.) and RS Newton International fellowship (C.P.-N.).

\section{REFERENCES}

(1) (a) Hashmi, A. S. K. Chem. Rev. 2007, 107, 3180. (b) Li, Z. G.; Brouwer, C.; He, C. Chem. Rev. 2008, 108, 3239. (c) Huang, H.; Zhou, Y.; Liu, H. Beilstein J. Org. Chem. 2011, 7, 897. (d) Dorel, R.; Echavarren, A. M. Chem. Rev. 2015, 115, 9028.

(2) (a) McKay, M. J.; Nguyen, H. M. ACS Catal. 2012, 2, 1563. (b) Li, X. H.; Zhu, J. L. J. Carbohydr. Chem. 2012, 31, 284. (c) Li, X. H.; Zhu, J. L. Eur. J. Org. Chem. 2016, 2016, 4724. (d) Peng, P.; Schmidt, R. R. J. Am. Chem. Soc. 2015, 137, 12653. (e) Medina, S.; Galan, M. C. Carbohydr. Chem. 2015, 41, 59. (f) Benito-Alifonso, D.; Galan, M. C. Bronsted and Lewis Acid Catalyzed Glycosylation. In Selective Glycosylations - Synthetic Methods and Catalysts; Bennet, C., Ed.; Wiley-VCH, 2017.

(3) For examples of $\mathrm{Au}(\mathrm{III})$ activation: (a) Hotha, S.; Kashyap, S. J. Am. Chem. Soc. 2006, 128, 9620. (b) Mamidyala, S. K.; Finn, M. G. J. Org. Chem. 2009, 74, 8417. (c) Kayastha, A. K.; Hotha, S. Chem. Commun. 2012, 48, 7161. (d) Sureshkumar, G.; Hotha, S. Chem. Commun. 2008, 4282. (e) Vidadala, S. R.; Thadke, S. A.; Hotha, S. J. Org. Chem. 2009, 74, 9233. (f) Thadke, S. A.; Mishra, B.; Hotha, S. J. Org. Chem. 2014, 79, 7358. (g) Li, Y.; Yang, Y.; Yu, B. Tetrahedron Lett. 2008, 49, 3604. (h) Li, Y.; Yang, X. Y.; Liu, Y. P.; Zhu, C. S.; Yang, Y.; Yu, B. Chem. - Eur. J. 2010, 16, 1871. (i) Tang, Y.; Li, J. K.; Zhu, Y. G.; Li, Y.; Yu, B. A. J. Am. Chem. Soc. 2013, 135, 18396. (j) Zhu, Y. G.; Yu, B. Chem. - Eur. J. 2015, 21, 8771. For examples of $\mathrm{Au}(\mathrm{I})$ activation: (k) Mishra, B.; Neralkar, M.; Hotha, S. Angew. Chem., Int. Ed. 2016, 55, 7786. (1) Adhikari, S.; Baryal, K. N.; Zhu, D. Y.; Li, X. H.; Zhu, J. L. ACS Catal. 2013, 3, 57.

(4) McCranie, E. K.; Bachmann, B. O. Nat. Prod. Rep. 2014, 31, 1026. (5) (a) Baryal, K. N.; Zhu, D. Y.; Li, X. H.; Zhu, J. L. Angew. Chem., Int. Ed. 2013, 52, 8012. (b) Kaneko, M.; Herzon, S. B. Org. Lett. 2014, 16, 2776. (c) Pradhan, T. K.; Lin, C. C.; Mong, K. K. T. Org. Lett. 2014, 16, 1474. (d) Issa, J. P.; Bennett, C. S. J. Am. Chem. Soc. 2014, 136, 5740. (e) Wang, H.; Tao, J. Y.; Cai, X. P.; Chen, W.; Zhao, Y. Q.; Xu, Y.; Yao, W.; Zeng, J.; Wan, Q. Chem. - Eur. J. 2014, 20, 17319. (f) Song, W. Z.; Zhao, Y.; Lynch, J. C.; Kim, H.; Tang, W. P. Chem. Commun. 2015, 51, 17475. (g) Das, S.; Pekel, D.; Neudorfl, J. M.; Berkessel, A. Angew. Chem., Int. Ed. 2015, 54, 12479. (h) Thombal, R. S.; Jadhav, V. H. RSC Adv. 2016, 6, 30846. (i) Nogueira, J. M.; Bylsma, M.; Bright, D. K.; Bennett, C. S. Angew. Chem., Int. Ed. 2016, 55, 10088. (j) Tanaka, H.; Yoshizawa, A.; Takahashi, T. Angew. Chem., Int. Ed. 2007, 46, 2505. (k) Verma, V. P.; Wang, C. C. Chem. - Eur. J. 2013, 19, 846. (1) Zhu, D. Y.; Adhikari, S.; Baryal, K. N.; Abdullah, B. N.; Zhu, J. L. J. Carbohydr. Chem. 2014, 33, 438. (m) Liu, D. S.; Sarrafpour, S.; Guo, W.; Goulart, B.; Bennett, C. S. J. Carbohydr. Chem. 2014, 33, 423. (n) Zhu, D. Y.; Baryal, K. N.; Adhikari, S.; Zhu, J. L. J.
Am. Chem. Soc. 2014, 136, 3172. (o) Beale, T. M.; Moon, P. J.; Taylor, M. S. Org. Lett. 2014, 16, 3604.

(6) (a) Balmond, E. I.; Coe, D. M.; Galan, M. C.; McGarrigle, E. M. Angew. Chem., Int. Ed. 2012, 51, 9152. (b) Balmond, E. I.; BenitoAlifonso, D.; Coe, D. M.; Alder, R. W.; McGarrigle, E. M.; Galan, M. C. Angew. Chem., Int. Ed. 2014, 53, 8190. (c) Beattie, R. J.; Hornsby, T. W.; Craig, G.; Galan, M. C.; Willis, C. L. Chem. Sci. 2016, 7, 2743. (d) Medina, S.; Harper, M. J.; Balmond, E. I.; Miranda, S.; Crisenza, G. E. M.; Coe, D. M.; McGarrigle, E. M.; Galan, M. C. Org. Lett. 2016, 18, 4222. (e) Palo-Nieto, C.; Sau, A.; Williams, R.; Galan, M. C. J. Org. Chem. 2017, 82, 407.

(7) (a) Medina, S.; Henderson, A.; Bower, J.; Galan, M. C. Chem. Commun. 2015, 51, 8939. (b) Sau, A.; Williams, R.; Palo-Nieto, C.; Franconetti, A.; Medina, S.; Galan, M. C. Angew. Chem., Int. Ed. 2017, 56, 3640. (c) Sau, A.; Galan, M. C. Org. Lett. 2017, 19, 2857.

(8) Although we show that ester groups are tolerated elsewhere in the glycal donor (Table 3, entry 1 ), this result is not completely surprising, since the presence of a deactivating ester group at C-3 near the reacting double bond is known to significantly decrease the reactivity of the glycal donor. ${ }^{6 a}$

(9) (a) Nguyen, R. V.; Yao, X. Q.; Bohle, D. S.; Li, C. J. Org. Lett. 2005, 7, 673. (b) Zhang, Z. B.; Liu, C.; Kinder, R. E.; Han, X. Q.; Qian, H.; Widenhoefer, R. A. J. Am. Chem. Soc. 2006, 128, 9066.

(10) Yang, C. G.; He, C. J. Am. Chem. Soc. 2005, 127, 6966.

(11) When $\mathrm{Na}_{2} \mathrm{CO}_{3}$ is added, the proton is sequestered stopping the cycle. However, ${ }^{1} \mathrm{H}$ NMR mixtures of $1 \mathrm{a}$ and $2 \mathrm{a}$, Au-catalyst and the base still show the interaction with the alkene protons Figure S4 in ESI. 